\title{
Ustawa budżetowa na 2014 rok - wybrane aspekty prawne
}

\section{The 2014 Budget Act: Selected Legal Aspects}

Streszczenie. Opracowanie przestawia treść prawną i układ ustawy budżetowej na 2014 rok. Regulacje zawarte w ustawie budżetowej - z punktu widzenia przepisów konstytucji i ustawodawstwa finansowego - wywołują różne pytania. Ustawa budżetowa jest ściśle związana z ustawą o finansach publicznych, która wyznacza elementy składowe ustawy budżetowej. Natomiast polskie ujęcia konstytucyjne dotyczące budżetu państwa są zbyt ogólne i w niewielkim stopniu zakreślają wymogi pod adresem ustawy budżetowej.

Słowa kluczowe: ustawa budżetowa; ustawa o finansach publicznych; konstytucja.

\begin{abstract}
The Budget Act for the year 2014 raises legal questions in the context of the provisions of the Constitution as well as the Public Finance Act from 2009. Polish constitutional provisions relating to the state budget may be described as too general. They specify the requirements with regard to the Budget Act only to a limited extent.
\end{abstract}

Keywords: The Budget Act; the Public Finance Act; the Constitution. 


\section{Przedmiot i cel opracowania}

Ustawa budżetowa na rok 2014 z dnia 24 stycznia 2014 r. ${ }^{1}$ ustala dochody, wydatki, deficyt, przychody, rozchody i inne elementy gospodarki budżetowej państwa na rok 2014. Ustawa zawiera 42 artykuły, jednak większość ustaleń ustawy budżetowej ujęta jest w załącznikach, których jest 19. Załącznik do ustawy budżetowej jest integralną częścią ustawy, ma on znaczenie prawnie wiążące ${ }^{2}$. Ustawa budżetowa na 2014 r., łącznie z załącznikami, jest obszernym dokumentem prawnym liczącym kilkaset stron.

Celem opracowania jest przestawienie treści prawnej i układu ustawy budżetowej oraz charakteru i znaczenia prawnego jej postanowień. Chodzi także o ocenę ustawy budżetowej na 2014 r. w aspekcie wymogów prawnych. Regulacje ustawy budżetowej - z punktu widzenia przepisów konstytucji i ustawodawstwa finansowego - wywoływać mogą różne pytania i wątpliwości.

\section{Termin uchwalenia ustawy}

Ustawa została wydana (po przejściu przez poszczególne etaty procedury budżetowej) w dniu 24 stycznia 2014 r. Weszła w życie z dniem ogłoszenia (tj. z dniem 3 lutego 2014 r.) z mocą od dnia 1 stycznia 2014 r. Do dnia jej ogłoszenia miał jednak miejsce stan, w którym nie istniał budżet jako ustawa - akt parlamentu. Zgodnie z art. 219 ust. 4 Konstytucji z 1997 r. $^{3}$ gospodarka finansowa państwa prowadzona jest wtedy na podstawie projektu ustawy budżetowej. Od dnia 1 stycznia do dnia 2 lutego 2014 r. „obowiązywał” więc rządowy projekt budżetu.

Sądzę, że brak budżetu (jako ustawy) i obowiązywanie do czasu ogłoszenia ustawy budżetowej projektu przygotowanego przez rząd osłabia pozycję prawną sejmu i senatu. Jeżeli budżet nie jest uchwalony przed

\footnotetext{
Dz.U., poz. 162.

Por. T. Grodyński, Zasady gospodarstwa budżetowego w Polsce na tle porównawczym, Kraków 1932, s. 99.

Dz.U. Nr 78, poz. 483 ze zm.
} 
rozpoczęciem nowego okresu budżetowego, to w wielu konstytucjach dla takich przypadków - wprowadzana jest instytucja prorogacji budżetowej (przedłużenia budżetu poprzedniego na następny rok). Z punktu widzenia pozycji budżetowej parlamentu obecne rozwiązanie (obowiązywanie projektu rządowego) powinno być zmienione. Należy rozważyć wprowadzenie do Konstytucji prorogacji budżetowej lub innego uregulowana (np. takiego, jakie stosowano w konstytucjach II Rzeczypospolitej lub które przewiduje współcześnie konstytucja Francji).

\section{Ustalenia ustawy budżetowej na 2014 rok i ich znaczenie prawne}

Na kształt prawny ustawy budżetowej składa się część główna (artykułowa), załączniki, a także inne postanowienia. Dochody i wydatki ujęte w załącznikach podzielone są na części, działy i rozdziały budżetowe. Postanowienia załączników do ustawy budżetowej (zwłaszcza załącznika nr 2) określają granice wydatków w poszczególnych częściach, działach i rozdziałach. Są upoważnieniem do wydatkowania środków budżetowych skierowanym do dysponentów części budżetowych (do ministrów) i innych dysponentów budżetowych.

Konstytucja RP z 2 kwietnia 1997 r. nie określa treści i kształtu ustawy budżetowej ${ }^{4}$. Treść ustawy budżetowej określają natomiast odpowiednie przepisy ustawy z 29 sierpnia 2009 r. o finansach publicznych ${ }^{5}$, zwłaszcza art. art.: 109, 110, 114, 115, 116, 117, 119, 121, 122.

Art. 1 ust. 1 ustawy budżetowej na 2014 r. ustala łączną kwotę podatkowych i niepodatkowych dochodów budżetu państwa w wysokości 277782224 tys. zł. Ustalenie wysokości tych dochodów (np. z podatku od towarów i usług, podatku akcyzowego, podatków dochodowych, dywidend) wykazuje załącznik nr 1. W ust. 2 ustala się - zgodnie z załącznikiem nr 2 - łączną kwotę wydatków budżetu państwa w wysokości

\footnotetext{
4 C. Kosikowski, Finanse publiczne w świetle Konstytucji RP oraz orzecznictwa Trybunału Konstytucyjnego (na tle porównawczym), Warszawa 2004, s. 81.

$5 \quad$ Tekst jedn. Dz.U. z 2013 r., poz. 885 ze zm., dalej: u.f.p.
} 
325287369 tys. zł. Konsekwencją powyższych ustaleń o wysokości dochodów i wydatków jest regulacja ust. 3, ustalająca deficyt budżetu państwa na 31 grudnia 2014 r. na kwotę nie większą niż 47505145 tys. zł. Kwota deficytu budżetowego jest różnicą pomiędzy wskazanymi wyżej wydatkami a planowanymi dochodami.

W art. 2 ustalano kwoty dochodów (77 957123 tys. zł), wydatków (78 348825 tys. zł) i deficyt (391 702 tys. zł) budżetu środków europejskich, który jest wyodrębnionym elementem ustawy budżetowej. Jego dochody (pochodzące z budżetu UE) i wydatki (finansujące krajowe i regionalne programy operacyjne) można oceniać jako dochody i wydatki o szczególnych cechach, będące wyrazem powiązania budżetu państwa z budżetem UE ${ }^{6}$. Dochody budżetu środków europejskich uszczegółowione są w załączniku nr 3, a wydatki w załączniku nr 4.

W załączniku nr 3 dochody budżetu środków europejskich ustalone są według programów operacyjnych (krajowych, regionalnych) i innych, w tym programu Wspólna Polityka Rolna. W załączniku nr 4 ustalone są wydatki budżetu środków europejskich w układzie części, działów i programów operacyjnych.

W art. 3 ustala się łączną kwotę planowanych przychodów budżetu państwa, czyli głównie wpływów pożyczkowych, uzyskiwanych w następstwie sprzedaży obligacji skarbowych, w wysokości 426183364 tys. zł oraz łączną kwotę planowanych rozchodów budżetu państwa (czyli spłat zadłużenia) w wysokości 378286517 tys. zł. Przychody i rozchody określa załącznik nr 5. Planowane saldo przychodów i rozchodów budżetu państwa (łączna kwota wskazanego wyżej deficytu budżetu państwa i deficytu budżetu środków europejskich) ustalone zostało (w art. 3 ust. 2) na kwotę 47896847 tys. zł.

Według art. 4 źródłem pokrycia potrzeb pożyczkowych budżetu państwa, w tym pokrycia deficytu budżetu państwa, są: środki pozostające na rachunkach budżetu państwa w dniu 31 grudnia 2013 r., przychody z tytułu sprzedaży skarbowych papierów wartościowych, przychody z prywaty-

6 Por. W. Miemiec, Komentarz do art. 117-121 ustawy o finansach publicznych, [w:] M. Karlikowska, W. Miemiec, Z. Ofiarski, K. Sawicka, Ustawa o finansach publicznych. Komentarz, Wrocław 2010, s. 309-325. 
zacji, przychody z tytułu kredytów i pożyczek, przychody z innych tytułów. Przepis ten wskazuje na finansowanie zadań budżetowych przy pomocy źródeł o charakterze zwrotnym (ze sprzedaży skarbowych papierów wartościowych, z kredytów i pożyczek), podnosi znaczenie środków na rachunkach budżetu państwa. Dotyczy on zachowania płynności (wypłacalności) budżetu. Brak środków na rachunkach budżetowych byłby oznaką, że „kasa” lub „skarb” są puste.

Art. 5 ustawy budżetowej ustala, że przyrost zadłużenia na dzień 31 grudnia 2014 r. z tytułu zaciągniętych i spłaconych kredytów lub pożyczek oraz emisji i spłaty skarbowych papierów wartościowych nie może przekroczyć kwoty 85000000 tys. zł. Z art. 5 nie wynika wprost, o jaki przyrost zadłużenia chodzi. Wydaje się, że chodzi o przyrost zadłużenia Skarbu Państwa związanego z deficytem budżetu państwa, a także przyrost zadłużenia niezwiązanego z finansowaniem deficytu budżetowego.

Jak należy rozumieć znaczenie prawne art. 5, który dotyczy limitu przyrostu zadłużenia? Sądzę, że trzeba przepis ten traktować jako upoważnienie parlamentu (przyznane ustawą) do powiększenia zadłużenia publicznego. Upoważnienie to uzyskuje rząd (minister finansów). Jest ono elementem upoważnień zawartych w ustawie budżetowej. Zauważyć trzeba, że udzielone upoważnienie do wzrostu zadłużenia (do kwoty 85 mld zł) jest bardzo istotnym posunięciem ze strony ustawodawcy. Upoważnienie to znacznie przekracza kwotę zadłużenia spowodowaną planowanym deficytem budżetowym (wynoszącym ok. 47 mld zł). Można to wyjaśnić m.in. tym, że deficyt budżetu państwa jest tylko częścią deficytu całego sektora finansów publicznych, a także tym, że występują inne formy (rodzaje) długów rządowych, stosowanych w innych niż finansowanie deficytu budżetowego sprawach.

Sądzę, że odpowiedź na pytanie dotyczące różnicy między wysokością deficytu budżetowego (ok. 47 mld zł) a dopuszczalnym limitem przyrostem zadłużenia (85 mld zł) można też wyprowadzić z regulacji art. 6, 7 i 8 ocenianej ustawy budżetowej. Mówią one o poręczeniach, gwarancjach, limicie łącznych zobowiązań z tytułu gwarantowanych przez Skarb Państwa ubezpieczeń eksportowych i gwarancji ubezpieczeniowych (w wysokości 13 mld zł), upoważnieniu ministra finansów do dokonywa- 
nia wypłat ze środków budżetu państwa z tytułu kredytów i pożyczek udzielanych na podstawie umów międzynarodowych rządom innych państw (do kwoty 0,93 mld zł), upoważnieniu ministra finansów do udzielania ze środków budżetu państwa pożyczek: dla Banku Gospodarstwa Krajowego (do kwoty 2 mld zł), dla Bankowego Funduszu Gwarancyjnego (do kwoty 2 mld zł), dla jednostek samorządu terytorialnego (do kwoty 0,4 mld zł), dla Korporacji Ubezpieczeń Kredytów Eksportowych (do kwoty 0,835 mld zł), dla Funduszu Ubezpieczeń Społecznych (do kwoty 18 mld zł). Wskazane w art. 7 i 8 limity i upoważnienia wynoszą ponad 37 mld zł.

Istotne ustalenia budżetowe zawiera załącznik nr 5. Dotyczą one przychodów i rozchodów budżetu państwa oraz potrzeb pożyczkowych netto budżetu państwa i ich finansowania. Przychody i rozchody ujęte są jako: krajowe, zagraniczne oraz przychody i rozchody z tytułu prywatyzacji. W tej ostatniej grupie saldo jest ujemne (ok. 6,8 mld zł). Główną pozycją rozchodów tej grupy jest pozycja ujęta w punkcie „reforma systemu ubezpieczeń społecznych”, finansowana poprzez sprzedaż skarbowych papierów wartościowych. Są tu więc elementy finansowania deficytu budżetowego, formalnie ujęte w ramach ustaleń dotyczących spraw prywatyzacji.

W ramach rozchodów z prywatyzacji ustalone są także (w załączniku nr 5) odpisy na fundusze celowe (np. Fundusz Reprywatyzacji, Fundusz Restrukturyzacji Przedsiębiorców, Fundusz Skarbu Państwa, Fundusz Nauki i Technologii Polskiej), co sprawia, że niektóre pozycje rozchodów związane są z tworzeniem państwowych funduszy celowych. Sądzę, że wpływy z prywatyzacji i ich wykorzystanie powinny być zaliczane do dochodów i wydatków budżetowych, a nie przychodów i rozchodów budżetu.

Z załącznika nr 5 wynika także, że potrzeby pożyczkowe netto budżetu państwa ustalono na ok. 55,15 mld zł, czyli ok. 8 mld zł więcej niż ustalony deficyt budżetu państwa. Ponadto ustalone zostały w ramach potrzeb pożyczkowych netto budżetu państwa kwoty na „reformę systemu ubezpieczeń społecznych” (ok. 8,2 mld zł) oraz kwoty pożyczek i kredytów, które mają być udzielone (ok. 7,2 mld zł). Ustalenie poziomu deficy- 
tu sektora publicznego (nie tylko deficytu budżetu państwa) jest więc w świetle ocenianych regulacji - bardzo trudnym przedsięwzięciem.

Art. 9 ustawy budżetowej (oraz załącznik nr 6) regulują kwestie dotyczące wynagrodzeń w państwowej sferze budżetowej, m.in. kwoty wynagrodzeń dla osób objętych mnożnikowymi systemami wynagrodzeń i osób nieobjętych tymi systemami, kwoty bazowe dla określonych kategorii osób (np. członków korpusu służby cywilnej, żołnierzy zawodowych i funkcjonariuszy). Regulacja z art. 9 nawiązuje do wymogów ustawy z 23 grudnia 1999 r. o kształtowaniu wynagrodzeń w państwowej sferze budżetowej $^{7}$. Art. 14 ustala kwotę bazową dla zawodowych kuratorów sądowych (zgodnie z ustawą o kuratorach sądowych), art. 17 ustala limit mianowań oraz środki na wynagrodzenia i szkolenia dla służby cywilnej. Art. 15 ustala etaty Policji.

Aspekty finansowe powiązań państwa $\mathrm{z}$ jednostkami samorządu terytorialnego przewidują ustalenia art. $10 \mathrm{i}$ art. 28. Art. 10 (i załącznik nr 7) ustala zadania z zakresu administracji rządowej i inne zadania zlecone odrębnymi ustawami, a także dotacje celowe na finansowanie tych zadań. Dotacje te ustalone są w ramach budżetów wojewodów. Są one ujęte w podziale na dotacje celowe dla: gmin, powiatów i województw. Natomiast art. 28 ustawy budżetowej ustala kwoty wpłat wyrównawczych dla gmin (512 694 tys. zł), powiatów (1 078549 tys. zł), województw (914 738 tys. zł), o których stanowi art. 7 ust. 2 ustawy z 13 listopada 2003 r. o dochodach jednostek samorządu terytorialnego ${ }^{8}$.

Wykaz jednostek, dla których zaplanowano dotacje podmiotowe i celowe (oraz kwoty tych dotacji), ustala (według art. 11 ustawy) załącznik nr 8. W załączniku tym kwoty dotacji są ustalone w ramach części, działów, rozdziałów oraz poszczególnych jednostek lub ich grup. Przykładowo dotacje podmiotowe uzyskują: teatry, muzea, jednostki naukowe, szkoły wyższe, PKP Polskie Linie Kolejowe S.A., Agencja Restrukturyzacji i Modernizacji Rolnictwa, spółki wodne. Wykaz jednostek otrzymujących dotacje celowe jest długi, są to m.in. różne stowarzyszenia, funda-

Tekst jedn. Dz.U. z 2011 r. Nr 79, poz. 431 ze zm.

Tekst jedn. Dz.U. z 2010 r. Nr 80, poz. 526 ze zm. 
cje, organizacje, parki narodowe, oddziały Narodowego Funduszu Zdrowia, jednostki samorządu terytorialnego, inne jednostki.

Zakres i kwoty dotacji przedmiotowych i podmiotowych zawiera (wykonawczy w stosunku do art. 12) załącznik nr 9. Dotacje przedmiotowe to m.in. dotacje do niektórych zadań wykonywanych na rzecz rolnictwa, do krajowych przewozów pasażerskich z tytułu uprawnień do ulgowych przejazdów, do posiłków sprzedawanych w barach mlecznych. Dotacje podmiotowe to m.in. dotacje dla instytucji kultury, szkolnictwa wyższego, jednostek naukowych, innych jednostek sektora finansów publicznych (np. agencji państwowych), jednostek niezaliczonych do sektora finansów publicznych.

Według art. 13 zestawienie programów wieloletnich zawiera załącznik nr 10. Załącznik ten obejmuje ustalenia dotyczące 46 programów, m.in. programu wspierania niektórych inwestycji, programu ochrony brzegów morskich, programu poprawy bezpieczeństwa i warunków pracy, programu dotyczącego rozwoju metod produkcji ogrodniczej, programu zwalczania chorób nowotworowych, zadania modernizacji technicznej Sił Zbrojnych, programu budowy dróg krajowych, programu inwestycji kolejowych. Programy są ujęte w tzw. układzie zadaniowym (z podaniem odpowiednich mierników realizacji) i wskazaniem na koszty programu oraz nakłady w latach 2014-2016. Nakłady roku 2014 to ok. 9 mld zł.

Artykuły: 19, 20, 21, 22, 23, 24, 25, 26, 27 regulują kwestie wymagane przez przepisy z zakresu systemu ubezpieczeń społecznych. Są to m.in. następujące ustalenia: prognozowany średnioroczny wskaźnik cen towarów i usług konsumpcyjnych dla gospodarstw domowych emerytów i rencistów, kwota wydatków na prewencję rentową i na prewencję wypadkową, wysokość odpisów (kwot), o których mowa w art. 76 ust. 1 pkt 1 ustawy z 13 października 1998 r. o systemie ubezpieczeń społecznych ${ }^{9}$ i art. 32 ust. 2 ustawy z 19 grudnia 2008 r. o emeryturach pomostowych ${ }^{10}$, wysokość należności dla ZUS z tytułu poboru składek na rzecz otwartych

Tekst jedn. Dz.U. z 2013 r. poz. 1442 ze zm.

Dz.U. Nr 237, poz. 1656 ze zm. 
funduszy emerytalnych, prognozowane przeciętne miesięczne wynagrodzenie brutto w gospodarce narodowej ${ }^{11}$.

Art. 29 ustala obowiązkową składkę na Fundusz Pracy w wysokości 2,45\% podstawy wymiaru. Ustalenie tej składki w ustawie budżetowej jest wymagane przez art. 104 ust. 2 ustawy z 20 kwietnia 2004 r. o promocji zatrudnienia i instytucjach rynku pracy ${ }^{12}$. Z kolei art. 30 ustala obowiązkową składkę na Fundusz Gwarantowanych Świadczeń Pracowniczych w wysokości $0,10 \%$ podstawy wymiaru składki na ubezpieczenia emerytalne i rentowe, czego wymaga art. 29 ust. 2 ustawy z 13 lipca 2006 r. o ochronie roszczeń pracowniczych $\mathrm{w}$ razie niewypłacalności pracodawcy ${ }^{13}$. Przepisy te (art. 29 i art. 30) dowodzą, że ustawa budżetowa określa także wysokość procentową niektórych składek na dany rok budżetowy, a więc ustala nie tylko wysokość dochodów, wydatków i deficytu.

Art. 32, 33, 34 i 35 ustalają (zgodnie z załącznikami nr 11, nr 12, nr 13 i nr 14) plany finansowe agencji wykonawczych (10 agencji), instytucji gospodarki budżetowej (15 instytucji), państwowych funduszy celowych (28 funduszy, w tym Funduszu Ubezpieczeń Społecznych), niektórych państwowych osób prawnych (38osób).

W świetle art. 32 ustalone zostały plany finansowe: Agencji Rezerw Materiałowych, Polskiej Agencji Rozwoju Przedsiębiorczości, Narodowego Centrum Nauki, Narodowego Centrum Badań i Rozwoju, Agencji Mienia Wojskowego, Wojskowej Agencji Mieszkaniowej, Centralnego Ośrodka Badania Odmian Roślin Uprawnych, Agencji Restrukturyzacji i Modernizacji Rolnictwa, Agencji Nieruchomości Rolnych, Agencji Rynku Rolnego. Jest to zgodne z art. 122 u.f.p. Ujęcie w ustawie budżetowej planów finansowych państwowych agencji finansowanych z budżetu państwa jest wymogiem zasady zupełności (powszechności) budżetu.

\footnotetext{
11 Powiązania pomiędzy ustawą budżetową a funduszami ubezpieczeń społecznych przestawia J. Wantoch-Rekowski, System ubezpieczeń społecznych a budżet państwa. Studium prawnofinansowe, Warszawa 2014, s. 47 i n.

12 Tekst jedn. Dz.U. z 2013 r. poz. 674 ze zm.

13 Dz.U. Nr 158, poz. 1121 ze zm.
} 
Instytucje gospodarki budżetowej, których plany finansowe są załączone do ustawy budżetowej (por. art. 33 i załącznik nr 12), to m.in.: Centrum Usług Wspólnych, Centralny Ośrodek Dokumentacji Geodezyjnej i Kartograficznej, Centralny Ośrodek Sportu, Centrum Zakupów dla Sądownictwa, Centralny Ośrodek Informatyki, Centrum Usług Logistycznych, Centrum Badań i Edukacji Statystycznej GUS.

Wśród 28 planów finansowych państwowych funduszy celowych (załączonych do ustawy budżetowej - por. art. 34 i załącznik nr 13) są m.in.: Fundusz Promocji Kultury, Fundusz Rozwoju Kultury Fizycznej, Fundusz Nauki i Technologii Polskiej, Fundusz Modernizacji Sił Zbrojnych, Fundusz Pracy, Fundusz Gwarantowanych Świadczeń Pracowniczych, Fundusz Reprywatyzacji, Fundusz Restrukturyzacji Przedsiębiorców, Fundusz Wsparcia Policji, Państwowy Fundusz Rehabilitacji Osób Niepełnosprawnych, Fundusz Emerytalno-Rentowy, Fundusz Emerytur Pomostowych, Fundusz Ubezpieczeń Społecznych. Załączenie funduszów celowych do ustawy budżetowej zgodne jest z art. 122 i 123 u.f.p.

Niektóre fundusze celowe nie są jednak załączone do ustawy budżetowej. Są to fundusze prowadzone lub obsługiwane przez Bank Gospodarstwa Krajowego ${ }^{14}$. Poza ustawą budżetową na 2014 rok funkcjonują następujące fundusze celowe, realizujące zadania publiczne i oparte o środki publiczne (np. dotacje budżetowe, opłatę paliwową, inne):

- Krajowy Fundusz Drogowy, utworzony na mocy ustawy z 27 października 1994 r. o autostradach płatnych oraz o Krajowym Funduszu Drogowym $^{15}$,

- Fundusz Kolejowy, powołany na podstawie ustawy z 16 grudnia 2005 r. o Funduszu Kolejowym ${ }^{16}$,

- Fundusz Żeglugi Śródlądowej, powołany ustawą z 28 października 2002 r. o Funduszu Żeglugi Śródlądowej i Funduszu Rezerwowym",

14 Fundusze te i ich stosunek do ustawy budżetowej przedstawia M. Cilak, Instrumenty wspierania rozwoju gospodarczego stosowane przez samorzq̨d terytorialny, Toruń 2013, s. 63, 64, 80-89.

15 Tekst jedn. Dz.U. z 2012 r., poz. 931 ze zm.

16 Dz.U. z 2006 r. Nr 12, poz. 61 ze zm.

17 Dz.U. Nr 199, poz. 1672 ze zm. 
- Fundusz Termomodernizacji i Remontów, utworzony ustawą z 21 listopada 2008 r. o wspieraniu termomodernizacji i remontów ${ }^{18}$,

- Fundusz Pożyczek i Kredytów Studenckich, powołany ustawą z 17 lipca 1998 r. o pożyczkach i kredytach studenckich ${ }^{19}$,

- Fundusz Strefowy, utworzony ustawą z 2 października 2003 r. o zmianie ustawy o specjalnych strefach ekonomicznych i niektórych innych ustaw ${ }^{20}$,

- Krajowy Fundusz Kapitałowy, utworzony na mocy ustawy z 4 marca 2005 r. o Krajowym Funduszu Kapitałowym²1.

Art. 35 i załącznik nr 14 ustala plany finansowe niektórych państwowych osób prawnych (38 podmiotów). Są to m.in. plany finansowe: Rzecznika Ubezpieczonych, Urzędu Dozoru Technicznego, Polskiego Instytutu Sztuki Filmowej, Polskiego Klubu Wyścigów Konnych, Polskiej Agencji Żeglugi Powietrznej, Polskiej Organizacji Turystycznej, Narodowego Funduszu Ochrony Środowiska i Gospodarki Wodnej, parków narodowych, Zakładu Ubezpieczeń Społecznych. W przepisach tych nie ma ustaleń dotyczących planów finansowych przedsiębiorstw państwowych i spółek Skarbu Państwa, co jest przedmiotem różnych wątpliwości i postulatów $^{22}$. Warto zauważyć, że grupa budżetowa „Przedsiębiorstwa i zakłady” była elementem ustawy skarbowej w okresie II RP.

Art. 37, 38, 39 i 40 (a także będące ich rozwinięciem załączniki nr 15, 16, 1718 i 19) ustalają dochody i wydatki budżetu środków europejskich, wykaz programów finansowanych z udziałem środków budżetu Unii Europejskiej i inne ustalenia związane ze środkami europejskimi. W załączniku nr 15 ustalone są dochody i wydatki budżetu środków europejskich oraz budżetu państwa w 2014 roku i kolejnych latach, w ramach poszczególnych programów operacyjnych. Załącznik nr 16 wskazuje na

\footnotetext{
Dz.U. Nr 223, poz. 1459 ze zm.

Dz.U. Nr 108, poz. 685 ze zm.

Dz.U. Nr 188, poz. 1840 ze zm.

Dz.U. Nr 57, poz. 491 ze zm.

A. Borodo, Prawnobudżetowe aspekty tworzenia i funkcjonowania przedsiębiorstw państwowych oraz spółek Skarbu Państwa, [w:] I. Czaja-Hliniak (red.), Nauka prawa finansowego po I dekadzie XXI wieku. Księga pamiq̨tkowa dedykowana Profesorowi Apoloniuszowi Kosteckiemu, Kraków 2012, s. 48-49.
} 
instytucje zarządzające, nazwy programów, ustala limity zobowiązań i limity wydatków na poszczególne lata.

\section{Podsumowanie}

Ustawa budżetowa jest bardzo ściśle związana z ustawą o finansach publicznych, która wyznacza zawartość (treść i układ) ustawy budżetowej. Polskie ujęcia konstytucyjne dotyczące budżetu państwa są niestety zbyt ogólnikowe i w niewielkim stopniu zakreślają wymogi pod adresem ustawy budżetowej. Wymogi te ustala ustawa o finansach publicznych. Jednak ustawa ta nie jest aktem nadrzędnym w stosunku do ustawy budżetowej. Potrzebne są więc regulacje konstytucyjne dotyczące pozycji, treści i układu budżetu państwa

Z charakterystyki ustawy budżetowej na 2014 rok wynika, że wiele artykułów ustawy budżetowej powiązanych jest ściśle z odpowiednimi przepisami ustaw (np. z ustawą o wynagrodzeniach w państwowej sferze budżetowej, ustawami dotyczącymi ubezpieczeń społecznych, ustawą o dochodach jednostek samorządu terytorialnego, ustawami tworzącymi fundusze celowe i agencje wykonawcze, innymi ustawami). Ustawa budżetowa jest funkcją ustaw określających zadania i kompetencje organów państwa, ustala wydatki państwowe będące następstwem tych zadań i kompetencji.

Deficyt budżetowy określony w ustawie na 2014 r. nie odzwierciedla deficytu całego sektora publicznego. Jedynie budżet całościowy (zupełny) mówiłby o stanie równowagi budżetowej państwa i rzeczywistej wysokości deficytu publicznego (nie tylko budżetowego).

Państwowe fundusze celowe oraz inne jednostki sektora rządowego (m.in. agencje wykonawcze, państwowe osoby prawne), a także ustalenia finansowe dotyczące tych funduszy i osób wywołują pytania dotyczące zakresu budżetu. Utrzymywanie funduszy celowych (zarządzanych przez ministrów i obsługiwanych przez Bank Gospodarstwa Krajowego) poza ustawą budżetową jest naruszeniem zasad budżetowych (w szczególności zasady zupełności budżetu) i uniemożliwia prawne ustalenie i ocenę poziomu deficytu budżetowego. 
W ustawie budżetowej są ujmowane czasem bardzo drobne kwoty, podczas gdy finansowanie zadań przez niektóre fundusze celowe (np. Krajowy Fundusz Drogowy) i spółki Skarbu Państwa nie jest odzwierciedlone w ustawie budżetowej.

Historycznie rzecz biorąc, instytucja budżetu państwa powstała jako wyraz walki parlamentu i króla (władzy wykonawczej) o prawo decydowania o dochodach i wydatkach państwa. Wydaje się, że współczesny polski ustawodawca nie jest zainteresowany decydowaniem - w ustawie budżetowej - o sprawach finansowych państwa w sposób całościowy.

\section{Bibliografia:}

Borodo A., Prawnobudżetowe aspekty tworzenia i funkcjonowania przedsiębiorstw państwowych oraz spółek Skarbu Państwa, [w:] I. Czaja-Hliniak (red.), Nauka prawa finansowego po I dekadzie XXI wieku. Księga pamiq̨tkowa dedykowana Profesorowi Apoloniuszowi Kosteckiemu, Krakowskie Towarzystwo Edukacyjne sp. z o. o. - Oficyna Wydawnicza AFM, Kraków 2012.

Cilak M., Instrumenty wspierania rozwoju gospodarczego stosowane przez samorzq̨d terytorialny, TNOiK, Toruń 2013.

Grodyński T., Zasady gospodarstwa budżetowego w Polsce na tle porównawczym, Polska Akademia Umiejętności, Komitet Wydawnictw Ekonomicznych, Kraków 1932.

Kosikowski C., Finanse publiczne w świetle Konstytucji RP oraz orzecznictwa Trybunału Konstytucyjnego (na tle porównawczym), Wydawnictwo Sejmowe, Warszawa 2004.

Miemiec W., Komentarz do art. 117-121 ustawy o finansach publicznych, [w:] M. Karlikowska, W. Miemiec, Z. Ofiarski, K. Sawicka, Ustawa o finansach publicznych. Komentarz, PRESSCOM Sp. z o.o., Wrocław 2010.

Wantoch-Rekowski J., System ubezpieczeń społecznych a budżet państwa. Studium prawnofinansowe, Wolters Kluwer, Warszawa 2014. 